\title{
ANALISA SIKAP DAN PERILAKU NASABAH TERHADAP PRODUK SIMPEDA PADA PT BANK KALBAR CABANG MEMPAWAH
}

\author{
Harry Setiawan ${ }^{1)}$ \& Rafles Ginting ${ }^{2)}$ \\ ${ }^{1}$ Fakultas Ekonomi dan Bisnis, Universitas Tanjungpura \\ email: harrysetiawan@ekonomi.untan.ac.id \\ ${ }^{2}$ Fakultas Ekonomi dan Bisnis, Universitas Tanjungpura \\ email: raflesginting@ekonomi.untan.ac.id
}

\begin{abstract}
Kalbar Bank branch of Mempawah places the product position by establishing the attributes of product and profenent facility which expected to give influence to the customers decision on determining their choice on a product as its market strategy. The research on it bears attribute of achievable office location as the most interesting attribute. While the small minimum deposit becomes the most uninteresting attribute on costumer perception. Generally, the costumers expect for the friendly servicing from the bank official and the most establishing factor of costumers choice on Simpeda product is the credibility of Kalbar Bank as the trusted bank in public. The attitude is a stimulus which may attrack the costumers to buy a product. The expected attitude is surely the positif one, which depends on the attributes that belong to the products and also other proponent factors. The study through the attributes shows that all the costumers or respondents still trust on Simpeda of Kalbar Bank as their saving choice because the lack on one attribute may be compensated by the superiority of others. We may have as a conclusion that the costumers or respondents attitude of Simpeda of Kalbar Bank is categorized in good one.
\end{abstract}

Keywords: Customers Simpeda, Kalbar Bank, Attribute, Profenent Facility

\section{PENDAHULUAN}

Berbagai deregulasi dan kebijakan dalam bidang perbankan telah dilakukan pemerintah guna merangsang bank-bank dan lembaga keuangan lainnya untuk kembali pada prinsip manajemen perbankan yang wajar dan sehat. Kebijakan yang telah dilakukan memberikan hasil pada meningkatnya pertumbuhan dan pendirian lembaga keuangan. Kemudahan dalam pembukaan kantor dan cabang membuat persaingan antara bank semakin ketat serta menimbulkan efek kreativitas pada masing-masing bank untuk menciptakan sesuatu yang berbeda dalam hal mengumpulkan dana dari masyarakat dan menyalurkan dana-dana tersebut dalam bentuk kredit kepada pihak ke-tiga. Bank Kalbar yang sebelumnya disebut Bank Pembangunan Daerah merupakan salah satu bank konvensional terbesar yang berada di Kalimantan Barat. Bank Kalbar semakin terdorong dalam kondisi persaingan untuk melakukan efesiensi dan perbaikan, termasuk didalamnya diantaranya memperbaiki kualitas asset, system prosedur serta pemanfaatan teknologi guna peningkatan pelayanan kepada nasabah.

Lembaga keuangan yang masuk kedalam sistem perbankan adalah lembaga keuangan yang berdasarkan peraturan perundangan berfungsi menghimpun dana dari masyarakat dalam bentuk simpanan dan menyalurkannya kepada masyarakat dalam bentuk kredit 
atau bentuk-bentuk lainnya dan dalam kegiatannya memberikan jasa dalam lalu lintas pembayaran. Kondisi perekonomian yang sering berfluktuasi menyebabkan dana masyarakat yang dapat diserap terbatas dan menjadikan persaingan diantara bank semakin ketat. Persaingan ini ditandai dengan semakin banyak produk perbankan khususnya simpanan yang memiliki kreteria hampir sama. Untuk memenangkan persaingan, setiap produk harus mampu memperlihatkan keunggulan masing-masing apabila disandingkan dengan pesaing terdekat mereka. Setiap produk juga harus mampu mengkomunikasikan posisinya pada pasar. Dalam hal ini hendaknya pihak Bank Kalbar semakin termotivasi untuk melakukan perbaikan terus menerus.

Strategi perusahaan dalam mengkomunikasikan posisi produk mereka ke dalam benak konsumen dibentuk dengan menampilkan atributatribut yang dimiliki oleh suatu produk. Melalui atribut-atribut yang ditonjolkan pemasar dapat mempengaruhi perilaku nasabah dalam hal keputusan pembelian, salah satu faktor psikologis yang mempengaruhi putusan pembelian ini adalah sikap (attitude).

Di bidang pemasaran, memahami perilaku konsumen menjadi hal yang sangat penting. Oleh karena itu, penulis tertarik untuk melakukan penelitian bagaimana sikap dan perilaku nasabah terhadap produk simpanan PT Bank Kalbar dimasa persaingan yang kian kompetitif ini. PT Bank Kalbar dipilih menjadi objek penelitian dikarenakan Bank Kalbar merupakan bank konvensional kebanggaan milik masyarakat Kalimantan Barat yang memiliki jaringan kerja terluas di Kalimantan Barat.

\section{KAJIAN LITERATUR}

\subsection{Pengertian Pemasaran dan Manajemen Pemasaran}

Suatu perusahaan dalam kegiatan pemasaran hendaknya harus dimulai dengan terlebih dahulu mengetahui dan merumuskan keinginan dan kebutuhan konsumen, selanjutnya untuk merumuskan dan menyusun suatu kombinasi dan kebijaksanaan produk, promosi, harga dan tempat yang sebenarbenarnya sehingga dapat memuaskan konsumen dengan terpenuhinya kebutuhan dan keinginannya. Dari kegiatan pemasaran yang dilakukan oleh suatu perusahaan dapat diperoleh informasi mengenai kebutuhan konsumen, jumlah produksi yang dibutuhkan konsumen, selera konsumen, perilaku konsumen dan pesaing-pesaing produk perusahaan. Dari informasi yang diperoleh maka perusahaan dapat mempergunakan sebagai dasar untuk melakukan proses produksi, memasarkan produk yang dibutuhkan oleh konsumen, dengan demikian pemasaran merupakan salah satu faktor utama dalam siklus hidup perusahaan yang dimulai dan berakhir dengan kebutuhan, keinginan dan kepuasan konsumen.

Kotler (2002) mengatkan bahwa pemasaran merupakan suatu proses sosial yang didalamnya individu dan kelmpok mendapatkan apa yang mereka inginkan dengan menciptakan, menawarkan, dan secara bebas mempertukarkan produk yang bernilai dengan pihak lain. Sedangkan menurut Kartajaya 2006) memberikan usulan pemasaran sebagai: sebuah disiplin bisnis strategis yang mengarahkan proses penciptaan, penawaran, dan perubahan nilai dari inisiator kapada stakeholders-nya.

Dari defenisi di atas dapat disimpulkan bahwa pemasaran merupakan hasil interaksi dari banyak kegiatan, dan kegiatan tersebut beroperasi dalam suatu lingkungan yang dibatasi oleh perusahaan itu sendiri, ketentuan, peraturan maupun konsekuensi sosial bagi perusahaan. Dalam arti yang luas bukan hanya 
digunakan oleh perusahaan, namun juga dapat digunakan oleh individu, pemerintah daerah, negara dan lain sebagainya yang mengawali proses penciptaan, menawarkan, mempertukarkan value kepada para pelanggan, karyawan, shareholder, pamasok, dealer, bankir, publik dan lain sebagainya.

Untuk sebuah perusahaan dalam kegiatan pemasarannya berhubungan langsung dengan manajemen pemasaran yang tidak hanya terbatas pada menawarkan barang dan jasa, tetapi juga mengelola proses pertukaran dari sebelum adanya barang atau jasa hingga barang dan jasa tersebut berada ditangan konsumen. Untuk itu menajer pemasaran mempunyai tugas untuk merencanakan, mengorganisasi, memimpin, mengawasi kegiatan pemasaran yang dapat membantu dalam mencapai tujuan perusahaan sehingga kegiatan pemasaran perlu dikelola dengan cara dan metode yang tepat sehingga perlu adanya suatu pemahaman tentang manajemen pemasaran.

\subsection{Konsep Pemasaran}

Di dalam ilmu pemasaran dikenal beberapa konsep yang berkembang sesuai tuntutan zaman. Ada yang berorientasi pada produksi, produk, penjualan, dan pemasaran. Sejalan dengan semakin ketatnya persaingan, kemajuan di bidang teknologi informasi, maka akan muncul pula kebutuhan baru dan keinginan yang lebih tinggi dari pihak konsumen, sehingga dalam hal ini pihak perusahaan akan lebih kepada orientasi pemasaran yang didukung oleh konsep baru di bidang pemasaran yaitu pemasaran berwawasan sosial.

Konsep pemasaran (Kotler, 2002:4) : "Konsep pemasaran adalah suatu falsafah manajemen dalam bidang pemasaran yang berorientasi kapada kebutuhan dan keinginan konsumen dengan didukung oleh kegiatan pemasaran terpadu yang diarahkan untuk memberikan kepuasan konsumen sebagai kunci keberhasilan organisasi dalam usahanya mencapai tujuan yang telah ditetapkan".

Dari pendapat yang dikemukankan diatas maka dapat dikatakan bahwa konsep pemasaran dapat digambarkan sebagai tugas pokok perusahaan yang ditekankan pada pemenuhan kebutuhan dan keinginan pasar/konsumen. Dimana hal tersebut dapat dicapai kepuasan konsumen yang lebih tinggi dibandingkan yang diberikan oleh pesaing.

\subsection{Strategi Pemasaran}

Dalam rangka mencapai tujuan dan sasaran perusahaan untuk memperoleh laba yang optimal dan memberikan kepuasaan kepada konsumen, maka diperlukan suatu strategi pemasaran yang dimulai dengan pembuatan rencana pemasaran. Secara lebih lanjut dapat dikatakan bahwa didalamnya mencakup suatu kegiatan diantaranya menganalisa kesempatan pasar, meneliti dan memilih pasar sasaran, merencanakan strategi pemasaran, merencanakan program pemasaran dan melaksanakan serta mengendalikan usaha pemasaran.

Paul (1994) menyatakan bahwa strategi pemasaran merupakan pernyataan pokok tentang dampak yang diharapkan akan dicapai dalam hal permintaan pada pasar target tertentu. Pendekatan terinci untuk menerapkan strategi-strategi ini ditentukan lewat program-program pemasaran yang spesifik, seperti program periklanan, program promosi penjualan, program pengembangan produk, serta penjualan dan distribusi.

Sebuah perusahaan tidak akan mungkin dapat melayani seluruh segmen yang sangat luas dalam masyarakat seperti halnya perusahaan di bidang perbankan. Perusahaan harus bisa mengidentifikasi segmen pasar yang dapat dilayani secara 
efektif. Untuk itu menurut Philip Kotler mengemukakan untuk pemasaran sasaran ini para pemasar harus melakukan tiga langkah utama yaitu sebagai berikut (Kotler, 2002:292).

1. Mengidentifikasi dan memilah-milah kelompok pembeli yang berbeda-beda yang mungking akan meminta produk dan/atau bauran pemasaran tersendiri (segmentasi pasar).

2. Memilih satu atau lebih segmen pasar untuk dimasuki (pembidikan pasar).

Membentuk dan mengkomunikasikan manfaat utama yang membedakan produk perusahaan dengan produk lain di pasar (penempatan posisi pasar).

\section{METODE PENELITIAN}

Bentuk penelitian yang digunakan adalah survey dengan objek penelitian pada nasabah yang berdomisili di Kabupaten Pontianak.

\subsection{Data Primer}

Metode pengumpulan data yang dilakukan dengan penyebaran angket langsung kepada responden.

\subsection{Data Sekunder}

Data yang diperoleh dari studi pustaka berupa teori-teori yang ada dari berbagai sumber seperti buku-buku, literatur, majalah, jurnal dan artikel-artikel serta dokumen-dokumen dari Bank Kalbar cabang Mempawah.

\subsection{Metode Pengambilan sampel}

a. Populasi.

Populasi dalam penelitian ini adalah nasabah simpanan Bank Kalbar jenis Simpeda.

b. Sampel.

Sampel adalah sebagian dari populasi yang karakteristiknya hendak diteliti dan dapat mewakili keseluruhan populasi. Adapun karakteristik sampel yang hendak diambil adalah nasabah Bank Kalbar yang telah menabung selama dua tahun dan minimal 1 kali melakukan transaksi dalam sebulan.

c. Cara Pengambilan Sampel.

Sampel diambil sebanyak 100 orang responden, diambil dengan secara proposional berdasarkan jumlah nasabah di Bank Kalbar cabang Mempawah. Sedangkan tehnik pengambilan sampel berdasarkan purposive sampling.

\subsection{Variabel Penelitian}

Atribut yang digunakan dalam penelitian ini merujuk pada penelitian/ tesis saudara Chairul Mursyal yang dilakukan terhadap 60 orang responden pada bulan Desember 2002 dan Januari 2003, hasil pendapat responden dan hasil riset tersebut saudara Chairul Mursyal menyimpulkan terdapat 13 atribut yang menonjol dan mendukung pemasaran produk jasa simpanan sebuah bank. Adapun atribut-atribut yang digunakan adalah sebagai berikut:

1. Suku bunga yang diberikan.

2. Intensif hadiah yang diberikan (jenis hadiah, batasan hak nomor undian)

3. Proses pendaftaran, penyetoran dan penarikan simpanan

4. Lokasi kantor bank.

5. Biaya administrasi bulanan simpanan.

6. Pelayanan petugas

7. Kegiatan promosi

8. Bank enviroment (kondisi ruang kantor, tempat parkir dan lain-lain)

9. Reputasi Bank

10. Bentuk, tampilan dan desain buku simpanan.

\section{HASIL}

Setelah menganalisis bagaimana keyakinan dan evaluasi yang ada pada diri nasabah terhadap atribut yang ada pada produk Simpeda, maka berdasarkan rumus Fishbein diperoleh nilai sikap responden. Dari 13 atribut yang diteliti 
ternyata atribut yang paling diinginkan nasabah adalah atribut Sebagai Bank yang Terpecaya dengan nilai 4,48 diikuti dengan atribut Persyaratan Pendaftaran yang Mudah dengan nilai 2,69 dan atribut Pelayanan Petugas yang Ramah dan Kekeluargaan dengan nilai 2,43. Sedangkan yang dinilai tidak sesuai dengan harapan nasabah adalah atribut kegiatan promosi yang berkesinambungan dengan nilai sikap 0,29.

Sehingga penulis menyimpulkan bahwa kegiatan promosi yang dilakukan oleh pihak bank tidak diikuti dengan komunikasi yang baik, sehingga pesan dari kegiatan promosi tidak tersampaikan. Dalam tabel 1 diperoleh nilai rata-rata skor maksimum adalah 17,08, karena rentang skor +2 sebagai sangat baik dan 2 sebagai sangat buruk, maka penentuan rentang nilai maksimum adalah nilai skor rata-rata dibagi dua, sebagai berikut :

Tabel 1. Hasil Penelitian Sikap Responden

\begin{tabular}{|c|c|c|c|c|c|}
\hline $\begin{array}{c}\text { Rentang } \\
\text { Skor }\end{array}$ & $\begin{array}{c}+2 \\
\text { Sangat } \\
\text { Baik }\end{array}$ & $\begin{array}{c}+1 \\
\text { Baik }\end{array}$ & $\begin{array}{c}0 \\
\text { Ragu- } \\
\text { ragu }\end{array}$ & $\begin{array}{c}-1 \\
\text { Buruk }\end{array}$ & $\begin{array}{c}-2 \\
\text { Sangat } \\
\text { Buruk }\end{array}$ \\
\hline $\begin{array}{c}\text { Rentang } \\
\text { Nilai }\end{array}$ & 17,08 & 8,54 & 0 & $-8,54$ & 17,08 \\
\hline
\end{tabular}

Sumber: Data Olahan, 2019

Berdasarkan skala di atas, maka hasil penelitian sikap responden nasabah Simpeda Bank Kalbar bernilai 19,15 masuk kedalam kategori baik. Apabila penilaian sikap konsumen dilakukan secara menyeluruh terhadap semua atribut maka umumnya responden tetap bersikap positif terhadap produk simpanan di Bank Kalbar. Walaupun kegiatan promosi dianggap kurang baik namun keberadaan sebagai bank yang terpecaya cukup baik dipersepsi nasabah. Jadi, sacara umum responden/nasabah akan tetap memilih Simpeda sebagai produk pilihan mereka, karena kekurangan dalam satu atribut dikompensasi oleh keunggulan atribut lainnya.

\section{PEMBAHASAN}

5.1 Analisis Sikap Nasabah Terhadap Atribut Produk Simpeda Bank Kalbar

Variabel dasar yang menjadi alasan seseorang dalam melakukan tindakan pembelian adalah kebutuhan. Kemudian dilanjutkan pada proses pengambilan keputusan yang merupakan salah satu variabel pemikiran dalam sisi psikologis seseorang. Sedangkan sikap adalah evaluasi konsumen atas kemampuan atribut yang dimiliki sebuah produk dalam memenuhi kebutuhan tersebut.

Sikap juga merupakan hasil evaluasi yang mencerminkan rasa suka atau tidak suka seseorang terhadap suatu objek, sehingga dengan mengetahui hasil evaluasi tersebut perusahaan dapat memperkirakan seberapa besar potensi keinginan yang dimiliki oleh konsumen.

Model sikap dari Mertien Fishbein yang digunakan pada prinsipnya menghitung sikap seseorang terhadap suatu objek yang dikenali melalui atributatribut yang melekat pada objek tersebut. Dalam pengukuran sikap ini terdapat 2 komponen penting yaitu adanya keyakinan (belief) dan evaluasi yang ada pada diri konsumen terhadap atribut tertentu.

\subsection{Analisis Keyakinan}

Kepercayaan atau keyakinan konsumen adalah pengetahuan yang dimiliki konsumen dan kesimpulan yang dibuat tentang objek, atribut dan manfaatnya. Kepercayaan ini yang pada akhirnya membentuk suatu citra. Pengolahan data dari 100 orang Sangat Mudah dengan nilai rata-rata 0,92 . Sedangkan atribut Hadiah Undian yang Menarik dinilai tidak begitu penting bagi nasabah dengan nilai rata-rata 0,28.

Jadi dapat disimpulkan bahwa pelayanan petugas yang ramah dan kekeluargaan (service) dari pihak bank adalah hal yang paling utama dalam 
membentuk sikap nasabah terhadap produk simpanan dari sebuah bank.

\subsection{Analisis Sikap Nasabah}

Setelah menganalisis bagaimana keyakinan dan evaluasi yang ada pada didi nasabah terhadap atribut yang ada pada produk Simpeda, maka berdasarkan rumus Fishbein diperoleh nilai sikap responden. Dari 13 atribut yang diteliti ternyata atribut yang paling diinginkan nasabah adalah atribut Sebagai Bank yang Terpecaya dengan nilai 4,48 diikuti dengan atribut Persyaratan Pendaftaran yang Mudah dengan nilai 2,69 dan atribut Pelayanan Petugas yang Ramah dan Kekeluargaan dengan nilai 2,43. Sedangkan yang dinilai tidak sesuai dengan harapan nasabah adalah atribut Kegiatan Promosi yang Berkesinambungan dengan nilai sikap 0,29 .

Sehingga penulis menyimpulkan bahwa kegiatan promosi yang dilakukan oleh pihak bank tidak diikuti dengan komunikasi yang baik sehingga pesan dari kegiatan promosi itu tidak sampai.

\subsection{Analisis Norma Subjektif}

Analisis norma subjektif ini diperlukan sebagai salah satu variabel untuk memprediksi maksud atau keinginan berprilaku dari konsumen, dengan tujuan untuk mengetahui pengaruh kelompok referensi terhadap sikap dan perilaku seorang individu. Dalam kasus ini yang menjadi kelompok referensi adalah lingkungan keluarga dan teman. Hal ini dimaksudkan bahwa dalam menentukan pilihan suatu produk tabungan pada sebuah bank, seseorang tidak hanya berperilaku berdasarkan sikap sendiri, namun juga dipengaruhi pendapat keluarga dan temannya.

Norma subjektif ini merupakan alat ukur tanggapan nasabah yang terdiri dari faktor-faktor eksternal. Adapun faktor- faktor eksternal disini penulis hanya membatasi 2 variabel saja, yaitu :

a. Anggota keluarga ( suami/istri, orang tua, saudara dan anak )

b. Orang lain ( teman dan tetangga )

Untuk menghasilkan nilai Norma Subjektif (SN) diperlukan nilai keyakinan normatif (Normative Belief) yang dihubungkan dengan kebiasaan orang lain. Dari hasil tabulasi yang diperoleh dari kuesioner terhadap 100 responden diperoleh data sebagai berikut.

\subsection{Analisis Maksud Perilaku Nasabah Terhadap Produk Simpeda Bank Kalbar}

Model yang dikembangkan oleh Martien Fisbein tujuanya adalah untuk memprediksi perilaku. Model ini memiliki asumsi bahwa maksud yang dipandang sebagai anteseden (hal yang terjadi lebih dahulu) merupakan akibat langsung dari perilaku (ditentukan oleh komponen sikap atau pribadi seseorang) dan komponen normative atau sosial. Adapaun rumus yang digunakan untuk menganalisis maksud perilaku ini adalah: $B \approx B I=w 1(A B)+w 2(S N)$

Dimana:

$$
\begin{aligned}
& \text { B } \quad \text { = Perilaku } \\
& \text { B1 = Maksud perilaku } \\
& \text { AB }=\text { Sikap terhadap pelaksanaan } \\
& \text { perilaku b. } \\
& \text { SN } \quad=\text { Norma subjektif } \\
& \text { W1 W2 = Bobot yang ditentukan } \\
& \text { secara empiris, } \\
& \text { menggambarkan pengaruh } \\
& \text { relatif dari komponen. }
\end{aligned}
$$

Dalam penelitian ini untuk
menentukan bobot W1 dan W2
berdasarkan atribut-atribut produk
Simpeda yang ada, nasabah membentuk
pengalaman langsung dengan objek
dengan sedikit mempertimbangkan
faktor-faktor eksternal. Oleh sebab itu,


pemberian untuk bobot W1 lebih besar daripada W2 dengan asumsi W1 sebesar 0,6 dan bobot W2 sebesar 0,4. Bobot W1 lebih besar dari W2 karena W1 adalah bobot nilai sikap yang merupakan faktor internal dari individu yang mempengaruhi perilaku konsumen. Sedangkan W2 adalah bobot norma subjektif (SN) yang merupakan pengaruh eksternal dan sifatnya umum, akan tetapi dapat mempengaruhi individu dalam berprilaku. Maka dapat dihitung nilai maksud perilaku sebagai berikut

$$
\begin{aligned}
B \approx B I & =w 1(A B)+w 2(S N) \\
& =0,6(19,15)+0,4(1,3704) \\
& =11,49+0,54 \\
& =12,03
\end{aligned}
$$

Karena nilai B positif ( $>0$ ), maka perilaku nasabah terhadap produk Simpeda Bank Kalbar adalah baik. Jadi nasabah mempunyai tanggapan yang baik terhadap produk Simpeda Bank Kalbar yang disebabkan selain dari faktor internal (Sikap) yang positif, juga karena pendapat kelompok referensi yang juga positif terhadap produk simpanan tersebut.

\section{SIMPULAN}

Hasil analisis evaluasi atas keyakinan nasabah terhadap atribut yang diteliti diketahui bahwa nasabah merasa (komponen afektif dalam sikap) bahwa penilaian (evaluasi) terhadap layanan yang ramah dan kekeluargaan dari petugas bank adalah yang paling utama dalam membentuk sikap nasabah terhadap suatu produk simpanan/tabungan dari sebuah bank. Dari hasil analisis sikap nasabah pada 4 kantor Bank Kalbar wilayah kerja cabang Mempawah, diketahui nilai sikap yang tertinggi berada pada kantor cabang Mempawah dengan nilai 9,66. Sedangkan nilai sikap yang terendah adalah kantor kas Sui Duri dengan nilai 0,89.

Untuk faktor eksternal yang dapat mempengaruhi sikap adalah dari anggota keluarga dan orang lain sebagai variabel, alat ukur tanggapan menggunakan perhitugan norma subjektif diperoleh hasil bahwa rata-rata pihak keluarga lebih mendukung nasabah untuk menabung pada Simpeda Bank Kalbar dengan nilai skor 0,5699. Skor tersebut lebih tinggi dibandingkan teman-teman mereka dengan nilai skor 0,2662. Namun, untuk motivasi nasabah lebih didorong oleh teman-teman mereka dengan skor yang lebih tinggi yaitu sebesar 1,6916, dibanding dengan motivasi yang diperoleh dari pihak keluarga yang hanya sebesar 1,5799 .

Secara keseluruhan skor adalah positif yaitu dengan nilai 1,3704, maka dapat dikatakan secara umum baik keluarga maupun teman-teman pada prinsipnya setuju memilih Simpeda dari Bank Kalbar sebagai produk simpanan mereka. Dari hasil analisis maksud perilaku nasabah terhadap produk simpanan Simpeda dari Bank Kalbar diperoleh nilai maksud perilaku sebesar 12,03 positif (>0), maka dapat dikatakan secara umum perilaku nasabah terhadap produk Simpeda dari Bank Kalbar adalah baik.

\section{REFERENSI}

Hermawan Kartajaya, Muhammad Syakir Sula, Syariah Marketing (Bandung: PT Mizan Pustaka, 2006)

Philip Kotler, Manajemen Pemasaran, Edisi Milenium, Prenhallindo, 2002.

Joseph.P.Guiltinan, Gordon W. Paul, Diterjemahkan Agus Maulana, Strategi dan Program Manajemen Pemasaran, Edisi Kedua, Erlangga, 1994.

Ajzen, I., \& Fishbein, M. "Understanding Attitudes and Predicting Social Behavior, 1980.

Fishbein, M. and I. Ajzen. Belief, Attitude, Intention, and Behavior: An Introduction to Theory and Research. Addison-Wesley Pub. Co., 1975. 